\title{
Hepatitis E virus seroprevalence in Polish soldiers serving in harsh environmental conditions
}

\author{
Krzysztof Korzeniewski $^{1}$, Justyna Osińska ${ }^{2}$, Jolanta Korsak ${ }^{2}$, Monika Konior ${ }^{1}$ \\ ${ }^{1}$ Department of Epidemiology and Tropical Medicine, Military Institute of Medicine, Warsaw, Poland \\ ${ }^{2}$ Department of Clinical Transfusiology, Military Institute of Medicine, Warsaw, Poland
}

\begin{abstract}
Background: Hepatitis $E$ virus (HEV) is an under-recognised aetiological factor of viral hepatitis; it is most commonly transmitted via the oral-faecal route, but can also be transmitted by blood or blood products, vertically from an infected mother to the foetus or by transplanted organs. The aim of the study was to present the current seroprevalence of HEV among soldiers from the Polish Special Forces deployed on military operations carried out in harsh environmental conditions.

Materials and methods: The research conducted between October and November 2016 involved 253 active duty soldiers, 237 men and 16 women, aged 26-57, without clinical symptoms of infection, participants in military operations in Asia and Africa. Accurate HEV diagnosis required the implementation of a two-phase diagnostic protocol. During the first phase, immunoenzymatic ELISA method was used to detect specific anti-HEV antibodies (IgM and IgG) in blood serum samples indicating contact with an infectious agent in the past. During the second phase, serum samples obtained from subjects with positive or inconclusive test results were tested again using confirmatory recomLine HEV IgM/IgG immunoassay.

Results: Immunoenzymatic assay found anti-HEV antibodies (IgM and/or IgG) in blood serum samples obtained from 18 soldiers. Confirmatory tests were carried out among soldiers tested positive with ELISA or those with inconclusive test results; the confirmatory tests showed anti-HEV antibodies (IgM and/or IgG) in 16 of the studied soldiers, i.e. $6.3 \%$ of the study group.

Conclusions: The occurrence of HEV infections in Polish soldiers justifies the need for the introduction of screening tests for HEV in the military environment, especially among blood donors and in cases of whole blood or blood products transfusion.
\end{abstract}

(Int Marit Health 2018; 69, 2: 137-141)

Key words: hepatitis E virus (HEV), seroprevalence, Polish soldiers

\section{INTRODUCTION}

Military operations involving soldiers from the Polish Special Forces are often conducted in areas characterised by harsh environmental conditions, where the risk for infections, primarily those transmitted through the faecal-oral route, is particularly high. The risk is additionally increased by poor standards of sanitation and adverse climatic conditions. Although infectious diseases found among participants in military operations account for less than 3\% of all diagnoses, limited laboratory capabilities on missions abroad may lead to a misdiagnosis (some illnesses presenting with gastrointestinal symptoms and diagnosed as non-infectious may, in fact, be of infectious aetiology). This assumption is highly probable given the fact that over $50 \%$ of the military personnel deployed on operations overseas report diarrhoea, and the numbers of diarrhoea cases surge when hostilities intensify [1]. Acute gastrointestinal disorders are also a common health problem in Polish Military Contingents. Nonetheless, Polish soldiers reporting such problems only receive symptomatic treatment; the underlying cause of their illness is rarely identified. After completing their tour of duty abroad soldiers return to Poland where they undergo tests for infectious diseases. However, the number 
of laboratory tests offered is very limited and include microbiological diagnostics for Salmonella-Shigella and serological tests for hepatitis A, B, C, and syphilis [2].

Since Polish soldiers perform their mandatory tasks in areas characterised by poor sanitary standards where infectious diseases are hyperendemic, it is appropriate to stress the need to extend laboratory diagnostics aimed at detecting infections with different routes of transmission, in particular food and waterborne diseases, including hepatitis $\mathrm{E}$. This seems to be justified by the fact that hepatitis $E$ virus (HEV) infections are indeed found among military personnel deployed to areas of armed conflicts around Asia and Africa [3, 4]. The aim of the study was to present the current seroprevalence of HEV among soldiers from the Polish Special Forces serving in military operations carried out in harsh environmental conditions.

\section{MATERIALS AND METHODS \\ ETHICS}

The research project entitled "Prevalence of selected infections in the environment of soldiers from the Special Forces" was accepted by the Committee on Bioethics at the Military Institute of Medicine (Decision No. 41/2016, 15 July 2016) in accordance with the provisions of the Declaration of Helsinki (2013) and the rules elaborated by the European Union 'Good clinical practice for trials on medicinal products in the European Community. The rules governing medicinal products in the European Community' (1990) have been ratified by the Ethics Committee in Poland (March 1993).

\section{STUDY POPULATION}

The research conducted between October and November 2016 involved 253 active duty soldiers from the Polish Special Forces, 237 men and 16 women, aged 26-57, without clinical symptoms of infection, participants in military operations in Asia and Africa.

\section{LABORATORY PROCEDURES}

Detection of $\mathrm{HEV}$ infections required the implementation of a two-phase diagnostic protocol. During the first phase, immunoenzymatic ELISA test (Euroimmun, Germany) was used to detect specific anti-HEV antibodies (IgM and lgG) in blood serum samples indicating contact with an infectious agent in the past (according to manufacturer's instructions, results equal to or higher than $2.2 \mathrm{IU} / \mathrm{mL}$ have been interpreted as positive). During the second phase, whole blood samples were taken from subjects with positive or inconclusive test results, and tested with confirmatory recomLine HEV IgM/IgG immunoassay (Mikrogen, Germany; sensitivity HEV IgM 93.3\%, HEV IgG 96.6\%; specificity HEV IgM 96.9\%, HEV IgG 97.1\%). In soldiers tested positive with the ELISA, apart from performing confirmatory recomLine HEV IgM/IgG immunoassays, we have attempted to detect HEV RNA in blood specimens (GeneProof, Czech Republic). This method, however, proved unsuccessful and did not confirm the positive results, which might have been associated with only a brief presence of HEV RNA in blood.

\section{STATISTICAL ANALYSIS}

The statistical analysis has been performed using the statistical suite StatSoft. Inc. (2011) Statistica (data analysis software system), version 10.0 (SN JGNP3087539302AR-E) and Excel. The quantitative variables were characterised by the arithmetic mean of standard deviation or median or maximum/minimum (range). Statistical significance of differences between two groups (unpaired variables model) was processed with the t-Student test (or Welch test in the case of lack of homogeneity) or Mann-Whitney U test (in cases where conditions of performing the t-Student test were not satisfied or for variables measured by ordinal scale). Chi-squared tests for independence were used for qualitative variables. The qualitative variables were presented with the use of count and percentage. All tests were considered significant at $p=0.05$.

\section{RESULTS}

Immunoenzymatic assays carried out among 253 Polish soldiers found anti-HEV antibodies IgM in 2 blood serum samples and anti-HEV antibodies IgG in 17 samples. A total of 18 subjects tested positive for anti-HEV antibodies ( 1 soldier was positive for both anti-HEV antibodies IgM and $\lg G)$, they accounted for $7.1 \%$ of the study group.

During the second phase of the study task, confirmatory tests using recomLine HEV IgM/lgG immunoassay were carried out on whole blood samples taken from 18 of the soldiers, whose ELISA test results were positive (Table 1).

Confirmatory tests performed with recomLine HEV IgM/ /IgG assay found anti-HEV antibodies IgM (active infection) in 2 study subjects and anti-HEV antibodies IgG (contact with an infectious agent in the past) in 16 subjects. A total of 16 study patients tested positive for anti-HEV antibodies ( 2 soldiers tested positive for both anti-HEV IgM and $\operatorname{lgG}$ ), accounted for $6.3 \%$ of the entire study group. The socio-demographic variables of the 253 soldiers tested with the ELISA and confirmatory recomLine HEV assays are presented in Table 2.

The differences among the HEV-infected vs. HEV non-infected as regards the consumption of food and water from uncontrolled sources, consumption of pork or seafood, presence or absence of clinical symptoms (abdominal pain, nausea, vomiting, diarrhoea, fever, myalgia/arthralgia, jaundice), blood treatment in the past, vaccination against hepatitis $A$ and $B$ - were not statistically significant. 
Table 1. Positive and inconclusive test results in soldiers tested for hepatitis $E$ virus (HEV) infections with the ELISA and recomLine assays $(n=18)$

\begin{tabular}{lllll}
\hline Anti-HEV IgM ELISA & Anti-HEV IgG ELISA & RecomLine HEV IgM & RecomLine HEV IgG & Number of results \\
\hline Negative & Positive & Negative & Positive & 13 \\
Negative & Positive & Negative & Negative & 2 \\
Positive & Borderline & Positive & Positive & 1 \\
Positive & Positive & Positive & Positive & 1 \\
Borderline & Positive & Negative & Positive & 1
\end{tabular}

Table 2. Socio-demographic variables of soldiers tested for hepatitis $E$ virus (HEV) infection with the ELISA and recomLine assays $(n=253)$

\begin{tabular}{|c|c|c|c|}
\hline $\begin{array}{l}\text { Socio-demographic } \\
\text { variables }\end{array}$ & $\begin{array}{l}\text { HEV } \\
\text { infected } \\
(n=16) \\
\end{array}$ & $\begin{array}{l}\text { HEV non- } \\
\text {-infected } \\
(\mathrm{n}=237) \\
\end{array}$ & $\mathbf{P}$ \\
\hline Age [years] & & & 0.4451 \\
\hline $\begin{array}{l}\text { Mean } \pm \text { standard } \\
\text { deviation }\end{array}$ & $36.7 \pm 5.5$ & $38.1 \pm 5.3$ & \\
\hline Range & $29.0-45.0$ & $26.0-57.0$ & \\
\hline Gender & & & 0.2502 \\
\hline Women & $2(12.5 \%)$ & $13(5.5 \%)$ & \\
\hline Men & $14(87.5 \%)$ & 224 (94.5\%) & \\
\hline \multicolumn{2}{|c|}{$\begin{array}{l}\text { Consumption of water and food } \\
\text { from uncontrolled sources }\end{array}$} & & 0.4842 \\
\hline Yes & $5(31.3 \%)$ & 95 (40.1\%) & \\
\hline No & $11(68.7 \%)$ & 142 (59.9\%) & \\
\hline Symptoms & & & 0.8054 \\
\hline No symptoms & $15(93.8 \%)$ & 225 (94.9\%) & \\
\hline $\begin{array}{l}\text { Abdominal pain, } \\
\text { nausea, vomiting, } \\
\text { diarrhoea }\end{array}$ & $1(6.2 \%)$ & $9(3.8 \%)$ & \\
\hline $\begin{array}{l}\text { Fever, myalgia/ } \\
\text { /arthralgia, jaundice }\end{array}$ & $0(0.0 \%)$ & $3(1.3 \%)$ & \\
\hline Consumption of pork & & & 0.8970 \\
\hline Yes & $15(93.8 \%)$ & 224 (94.5\%) & \\
\hline No & $1(6.2 \%)$ & $13(5.5 \%)$ & \\
\hline $\begin{array}{l}\text { Consumption of } \\
\text { seafood }\end{array}$ & & & 0.8640 \\
\hline Yes & $10(62.5 \%)$ & $143(60.3 \%)$ & \\
\hline No & $6(37.5 \%)$ & $94(39.7 \%)$ & \\
\hline $\begin{array}{l}\text { History of blood } \\
\text { treatment }\end{array}$ & & & 0.4018 \\
\hline Yes & $0(0.0 \%)$ & $10(4.2 \%)$ & \\
\hline No & $16(100.0 \%)$ & 227 (95.8\%) & \\
\hline $\begin{array}{l}\text { Vaccination against } \\
\text { hepatitis } A \text { and } B\end{array}$ & & & 0.0699 \\
\hline Yes & $11(68.8 \%)$ & 203 (85.7\%) & \\
\hline No & $5(31.2 \%)$ & $34(14.3 \%)$ & \\
\hline
\end{tabular}

\section{DISCUSSION}

Hepatitis E virus is an under-recognised aetiological factor of viral hepatitis, which is primarily transmitted via the faecal-oral route (consumption of contaminated water or food), but can also be acquired by whole blood or blood products, vertically from an infected mother to the foetus or by transplanted organs. The risk for HEV infection is significantly higher in areas lacking proper hygiene and sanitation during the preparation of meals but also in all places around the world where virological screening of infected blood or blood products is unavailable. The most common classification of HEV identifies four main genotypes of the virus. Genotypes 1 and 2 are usually associated with outbreaks of HEV infections in humans reported from developing countries in Asia, Africa, and Central America (faecal-oral transmission). Genotype 3 (Europe, Northern America, Australia) and genotype 4 (Japan, China) are a major cause of infections in industrialised countries (oral route with zoonotic transmission as a result of the consumption of contaminated undercooked meat, particularly pork). Humans and their infected excrement remain the main reservoir and the major source of genotypes 1 and $2 \mathrm{HEV}$ infections, whereas genotypes 3 and 4 are primarily transmitted from animals (especially swine and wild boar) but sometimes also humans. Each year, an estimated 20 million people acquire the HEV infection globally; tens of thousands die from hepatitis $E[5,6]$. The infection, which is most often asymptomatic, may cause an acute self-limiting hepatitis, with symptomatic infection more commonly reported among older men (> 50 years) $[6,7]$. Clinical signs of hepatitis $E$ include nausea, vomiting, malaise, loss of appetite, and jaundice [8, 9]; but non-hepatic manifestations may also be seen, including a wide spectrum of neurological syndromes [10,11]. HEV infection may pose a serious threat to human life and health, especially in patients with drug-induced immunosuppression, solid organ recipients, AIDS patients, the elderly (natural immunosuppression), and pregnant women (during the $3^{\text {rd }}$ trimester an acute HEV infection may progress into fulminant hepatitis with the mortality rate reaching $25 \%$ ) [12].

The incidence of HEV infections has been steadily increasing over the last decade, mainly in high-income pop- 
ulations [13, 14], which may undoubtedly be associated with the transfer of infected immigrants from developing countries in the absence of virological screening among the newcomers. In the general populations of selected European countries, anti-HEV IgG rate ranges from $7.3 \%$ in Catalonia, Spain [15], 9.2\% in Sweden [16], to $16.8 \%$ in Germany [17]. Some countries have reported a high seroprevalence of HEV-positive blood donors, e.g. France and the Netherlands $[18,19]$. Also, extensive screening which has recently been carried out in Poland $(12,664$ donations from 22 blood transfusion centres) demonstrated high prevalence of HEV infections in blood donors [20].

Current knowledge about the prevalence of HEV in Poland is limited to the reports on specific antibody detection in wild animals [21], patients [22, 23], hunters [24], and 2 studies concerning blood donors [20,25]. The major studies carried out by Grabarczyk et al. [20] indicated a high level of HEV endemicity throughout Poland, which justifies the urgent need for protection of blood or blood products recipients against transfusion-transmitted HEV infection as well as the need for further population-based studies in order to assess the actual HEV prevalence in the Polish population.

This study, involving soldiers from the Polish Special Forces deployed on military operations carried out in harsh environmental conditions, had a number of limitations. The study group represented only $50 \%$ of the total manpower of the pre-selected military unit and approx. $10 \%$ of the Polish Special Forces manpower. The tests were performed in soldiers who have never been screened for HEV seroprevalence before: hence, it was impossible to determine where they had acquired the infection (the study participants have been repeatedly deployed on military operations overseas). The differences among the HEV-infected vs. HEV non-infected soldiers as regards the consumption of food and water from uncontrolled sources, blood treatment in the past, and preventive measures (vaccination against hepatitis $A$ and $B$, avoiding the consumption of pork and seafood in dining facilities of poor sanitary standards) were not statistically significant. Therefore, it was impossible to determine whether there was any connection between risk factors/health prevention and HEV occurrence. For accurate assessment of HEV seroprevalence in the Polish Armed Forces, especially in soldiers deployed on operations in harsh environmental conditions, it is necessary to extend the diagnostic panel of laboratory tests performed before and after deployment into the theatre of operations (preferably a two-phase diagnostic protocol: ELISA test for detection of specific anti-HEV IgM and IgG antibodies + confirmatory recomLine HEV IgM/IgG immunoassay in case of positive or inconclusive results), which will make it possible to identify carriers and symptomatic patients with non-specific gastrointestinal disorders, who may be the source of infection for other people in their local population.

\section{CONCLUSIONS}

The occurrence of HEV infections in Polish soldiers justifies the need for the introduction of screening tests for HEV in the military environment, especially among blood donors and whole blood or blood products recipients.

\section{ACKNOWLEDGEMENTS}

The study was supported by the Polish Ministry of Science and Higher Education (Subject No. 390/2016, entitled "Assessment of prevalence of selected infections in the military environment, Military Institute of Medicine in Warsaw, Poland"). The author is grateful to the medical team from the military unit No. 2305 in Warsaw for their excellent technical assistance and supervision in patient recruitment and collection of biological samples.

\section{CONFLICT OF INTEREST}

The author declares no conflicts of interests in relation to this article.

\section{REFERENCES}

1. Korzeniewski K. Health hazards in areas of military operations conducted in different climatic and sanitary conditions. Int Marit Health. 2011; 62(1): 41-62, indexed in Pubmed: 21534225.

2. Dziennik Ustaw 2016, poz. 946. Rozporządzenie Ministra Obrony Narodowej z dnia 13.06.2016 r. w sprawie urlopu aklimatyzacyjnego i turnusów leczniczo-profilaktycznych [in Polish].

3. Buisson $Y$, Coursaget $P$, Bercion R, et al. Hepatitis $E$ virus infection in soldiers sent to endemic regions. Lancet. 1994; 344(8930): 1165-1166, indexed in Pubmed: 7934527.

4. Coursaget $P$, Buisson $Y$, Enogat $N$, et al. Outbreak of enterically-transmitted hepatitis due to hepatitis A and hepatitis E viruses. J Hepatol. 1998; 28(5): 745-750, indexed in Pubmed: 9625307.

5. Global Infectious Diseases and Epidemiology Network. Hepatitis E, Worldwide. Available at. https://web.gideonline.com/web/epidemiology (Access: 29 Apr 2018).

6. Aspinall EJ, Couturier E, Faber M, et al. Country experts. Hepatitis E virus infection in Europe: surveillance and descriptive epidemiology of confirmed cases, 2005 to 2015. Euro Surveill. 2017; 22(26), doi: 10.2807/1560-7917.ES.2017.22.26.30561, indexed in Pubmed: 28681720.

7. Lapa D, Capobianchi MR, Garbuglia AR. Epidemiology of Hepatitis E Virus in European Countries. Int J Mol Sci. 2015; 16(10): 25711-25743, doi: 10.3390/ijms161025711, indexed in Pubmed: 26516843.

8. Dalton HR, Bendall R, ljaz S, et al. Hepatitis E: an emerging infection in developed countries. Lancet Infect Dis. 2008; 8(11): 698-709, doi: 10.1016/S1473-3099(08)70255-X, indexed in Pubmed: 18992406.

9. Riveiro-Barciela M, Rodríguez-Frías F, Buti M. Hepatitis E virus: new faces of an old infection. Ann Hepatol. 2013; 12(6): 861-870, indexed in Pubmed:24114815.

10. Pischke S, Behrendt P, Manns MP, et al. HEV-associated cryoglobulinaemia and extrahepatic manifestations of hepatitis E. Lancet Infect 
Dis. 2014; 14(8): 678-679, doi: 10.1016/S1473-3099(14)70823-0, indexed in Pubmed: 25056019.

11. Deroux A, Brion JP, Hyerle L, et al. Association between hepatitis $E$ and neurological disorders: two case studies and literature review. J Clin Virol. 2014; 60(1): 60-62, doi: 10.1016/j.jcv.2014.01.026, indexed in Pubmed: 24583064

12. Łapiński TW, Jaroszewicz J. Hepatitis E virus infection: a new threat for Europe. Przegl Epidemiol. 2016; 70(1): 11-4, 103, indexed in Pubmed:27344467.

13. Adlhoch C, Avellon A, Baylis SA, et al. Hepatitis E virus: Assessment of the epidemiological situation in humans in Europe, 2014/15. J Clin Virol. 2016; 82: 9-16, doi: 10.1016/j.jcv.2016.06.010, indexed in Pubmed: 27393938.

14. Pischke S, Behrendt P, Bock CT, et al. Hepatitis E in Germany: an under-reported infectious disease. Dtsch Arztebl Int. 2014; 111(35-36): 577-583, doi:10.3238/arztebl.2014.0577, indexed in Pubmed: 25249359.

15. Buti M, Domínguez A, Plans P, et al. Community-based seroepidemiological survey of hepatitis E virus infection in Catalonia, Spain. Clin Vaccine Immunol. 2006; 13(12): 1328-1332, doi: 10.1128/ CVI.00255-06, indexed in Pubmed: 17050741.

16. Olsen B, Axelsson-Olsson D, Thelin A, et al. Unexpected high prevalence of IgG-antibodies to hepatitis $\mathrm{E}$ virus in Swedish pig farmers and controls. Scand J Infect Dis. 2006; 38(1): 55-58, doi: 10.1080/00365540500321470, indexed in Pubmed: 16338839.

17. Faber MS, Wenzel JJ, Jilg W, et al. Hepatitis E virus seroprevalence among adults, Germany. Emerg Infect Dis. 2012; 18(10): 1654-1657, doi:10.3201/eid1810.111756, indexed in Pubmed: 23018055.

18. Mansuy JM, Legrand-Abravanel F, Calot JP, et al. High prevalence of anti-hepatitis $E$ virus antibodies in blood donors from South
West France. J Med Virol. 2008; 80(2): 289-293, doi: 10.1002/ jmv.21056, indexed in Pubmed: 18098159.

19. Hogema BM, Molier M, Slot Ed, et al. Past and present of hepatitis E in the Netherlands. Transfusion. 2014; 54(12): 3092-3096, doi: 10.1111/trf.12733, indexed in Pubmed: 24889277.

20. Grabarczyk P, Sulkowska E, Gdowska J, et al. Molecular and serological infection marker screening in blood donors indicates high endemicity of hepatitis $\mathrm{E}$ virus in Poland. Transfusion. 2018; 58(5): 1245-1253, doi: 10.1111/trf.14531, indexed in Pubmed: 29492976.

21. Larska M, Krzysiak MK, Jabłoński A, et al. Hepatitis E virus antibody prevalence in wildlife in Poland. Zoonoses Public Health. 2015; 62(2): 105-110, doi: 10.1111/zph.12113, indexed in Pubmed: 24655475.

22. Jaroszewicz J, Flisiak R, Kalinowska A, et al. Acute hepatitis E complicated by acute pancreatitis: a case report and literature review. Pancreas. 2005; 30(4): 382-384, indexed in Pubmed: 15841052.

23. Bura M, Michalak M, Chojnicki M, et al. Seroprevalence of anti-HEV IgG in 182 Polish patients. Postepy Hig Med Dosw (Online). 2015; 69: 320-326, doi: 10.5604/17322693.1143051, indexed in Pubmed: 25748623.

24. Sadkowska-Todys M, Baumann-Popczyk A, Wnukowska N, et al. Occurrence and prevalence of selected zoonotic agents: Echinococcus multilocularis, Trichinella spiralis and hepatitis E virus (HEV) in the population of Polish hunters-results of the study conducted in 2010-2012. Przegl Epidemiol. 2015; 69(4): 673-8, 823, indexed in Pubmed: 27139343.

25. Bura M, Łagiedo M, Michalak M, et al. Hepatitis E virus IgG seroprevalence in HIV patients and blood donors, west-central Poland. Int J Infect Dis. 2017; 61: 20-22, doi: 10.1016/j.jij. 2017.05.014, indexed in Pubmed: 28576599. 